\title{
ОРГАНІЗАЦІЯ НАВЧАННЯ СЛУХАЧІВ ЦИКЛІВ ІНТЕРНАТУРИ ТА СПЕЦІАЛІЗАЦІЇ ЗА ФАХОМ «КЛІНІЧНА ЛАБОРАТОРНА ДІАГНОСТИКА»
}

\author{
Львівський національний медичний університет імені Данила Галицького, м. Львів, Україна
}

\begin{abstract}
Мета - підбір нових інтерактивних методів навчання слухачів циклів інтернатури та спеціалізації за срахом «Клінічна лабораторна діагностика».

Матеріали і методи. Для оцінки існуючих та розробки нових методик інтерактивних методів навчання застосовано методи системного підходу та системного аналізу.

Результати. Запропоновано поряд із старими педагогічними методами, які визначаються як «пасивні» та «монолог», використання нових інтерактивних методів. Серед фрорм навчальної діяльності інтернів та слухачів нормам сучасної педагогіки найбільше відповідає метод кооперативних груп.

Висновки. Впровадження інтерактивних технологій навчання дозволить вирішити наступні навчальні цілі: розвиток критичного мислення у слухачів циклів інтернатури та спеціалізації за фрахом «Клінічна лабораторна діагностика», розширення їх комунікативної компетентності; формування здатності вибору оптимальних варіантів ефрективної взаємодії учасників; підвищення мотивації до навчання даної дисципліни; удосконалення професійного рівня слухачів та інтернів за фрахом «Лабораторна діагностика».
\end{abstract}

КЛЮЧОВІ СЛОВА: організація навчання, лабораторна діагностика, інтерактивні методи навчання, метод кооперативних груп, цикли інтернатури.

Первинна спеціалізація (інтернатура) $є$ обов'язковою формою післядипломної підготовки випускників усіх фракультетів вищих медичних навчальних закладів III-IV рівнів акредитації незалежно від підпорядкування та форми власності, після закінчення якої їм присвоюється кваліфрікація лікаря-спеціаліста з певного фаху. Навчання в інтернатурі за фрахом «Лабораторна діагностика» спрямоване на вивчення теоретичних знань, формування умінь і практичних навичок, необхідних лікарю-спеціалісту-лаборанту для самостійної роботи з основних розділів лабораторної діагностики [2;7]. Підготовка лікарів-лаборантів в інтернатурі проводиться за індивідуальними навчальними планами, розробленими на підставі типового навчального плану і програми інтернатури. Типовим навчальним планом передбачено: 5 місяців на базі стажування (780 год.), на кафедрі клінічної лабораторної діагностики та суміжних кафредрах 6 місяців навчання (936 год.).

Первинну спеціалізацію на кафедрах клінічної лабораторної діагностики здобувають лікарі, навчаючись в інтернатурі, та біологи, навчаючись на циклах спеціалізації. Кількісне співвідношення інтернів та слухачів спеціалізації протягом 20 років становило від 1 до 15 інтернів та 70-40 слухачів щороку.

Сучасні вимоги до профресійної діяльності і до процесу навчання спрямовані загалом на здатність вирішувати задачі, які постануть перед фра-

(c) О.Є. Січкоріз, 2016 хівцями у практичній діяльності. Досягти такого рівня підготовки спеціалістів старими педагогічними методами, які визначаються як «пасивні» та «монолог», неможливо [3;4;8].

Мета дослідження - підбір нових інтерактивних методів навчання слухачів циклів інтернатури та спеціалізації за фрахом «Клінічна лабораторна діагностика».

Матеріали і методи. Застосовано методи системного підходу та системного аналізу для оцінки існуючих та розробки нових методик інтерактивних методів навчання.

Результати дослідження та їх обговорення. Нами запропоновано «інтерактивні» методи, які стимулюють пізнавальну активність та самостійну роботу слухачів (інтернів). Інтерактивні методи навчання, на відміну від традиційних, ґрунтуються на активній взаємодії учасників навчального процесу, де основною $є$ взаємодія слухачів між собою, що дозволяє активізувати навчальний процес, зробити його цікавішим та менш виснажливим для учасників. Основними ознаками цих методів навчання $€$ самостійна робота, проблемні і творчі завдання, питання слухачів (інтернів) до викладача і все те, що розвиває творче мислення, забезпечує постійну, активну взаємодію всіх учасників процесу навчання, передбачає моделювання життєвих ситуацій, спільне розв'язання проблем [8;10].

Серед сучасних інтерактивних методів навчання виділяють: метод конкурентних груп, метод коо- 
перативних груп, кейс-метод, метод мозкового штурму, метод практичного ситуаційного тренінгу, метод міждисциплінарних конференцій тощо [1;3-6].

Серед форм навчальної діяльності інтернів та слухачів нормам сучасної педагогіки найбільше відповідає метод кооперативних груп. За кооперативної форми організації навчальної діяльності основна роль відведена спілкуванню та взаємодії слухачів один 3 одним [10]. Ознаки колективної роботи: наявність у всіх учасників спільної мети; поділ праці, фрункцій і обов'язків; співпраця і товариська взаємодопомога; суспільно корисна діяльність усіх і кожного зокрема.

Еорективність методу кооперативних груп полягає в тому, що обсяг роботи, виконаний групою, завжди є більшим, ніж виконаний кожним з їі членів. Спільні дії у малих групах, обговорення матеріалу з іншими, навчання один одного дають можливість краще зрозуміти матеріал, опанувати необхідні навички і вміння [8;10]. Співпраця у групі зумовлює вищий рівень досягнень і більшу продуктивність, зростання самоповаги її учасників. Метод кооперативних груп дозволяє розвинути творче мислення, провести взаємне навчання, вдосконалення шляхом багатосторонньої комунікації, залучити всіх, без винятку, слухачів у процес обговорення та обґрунтування власної думки, розвинути вміння вести професійну дискусію, виховати повагу до колег та альтернативних ідей і пропозицій, створює оптимальні умови для створення колективного інтелектуального продукту.

Залежно від кількості учасників групи фрормують по 3-6 осіб (2 і більше груп). Не практикують групи з двох осіб, які забезпечують високий рівень обміну інфрормацією, однак низький рівень розбіжності думок. Також розбіжність думок складніше подолати в групі 3 парною кількістю членів.

Найчастіше слухачів розподіляють на групи 3 урахуванням зацікавленості певною клінічною проблемою. Доцільно комплектувати групи слухачів за принципом однакового рівня академічної успішності. Така однорідність сприяє однаковим темпам обробки матеріалу і запобігає пасивності окремих її членів, які покладаються на більш обізнаних колег [2;5;10].

Перед фрормуванням груп перед слухачами чітко ставлять певні критерії їх оцінювання.

Метод кооперативних груп в інтерактивному навчанні можна реалізувати у фрормі диспуту, дискусії, дебатів, «круглого столу» або створення проблемної ситуації через рольову гру [1;5].

Обов'язковою умовою ефективності занять $€$ ставлення до слухачів як до рівноправних учасників процесу навчання. Слухач не повинен боятися висловлювати будь-яку свою думку, навіть хибну, поставити несподіване запитання, перейти до обговорення супутніх проблем. Викладач по- винен бути готовим до виникнення нестандартних ситуацій, висловлювання різних думок щодо вирішення завдання. Тому він має бути висококваліфікованим фахівцем, надавати слухачам необхідну інформацію, скеровувати дискусію у потрібному напрямку, бути спостерігачем, модератором, а не активним учасником [10].

На підготовчому етапі викладач фрормує групи, забезпечує переліком джерел фрахової літератури, алгоритмами, питаннями і задачами різного ступеня складності, клінічними і лабораторними даними, відеофільмами тощо, відповідно до теми заняття. Кожною групою розробляється план вирішення однієї клінічної проблеми з різних точок зору.

Надалі викладач спостерігає за ходом дискусії, відмічає відповідність варіантів вирішення клінічної проблеми. Важливим моментом $€$ виявлення слухача-лідера. Усі відповіді обґрунтовуються та коментуються слухачами і коригуються викладачем. Таким чином, усі слухачі залучені до навчального процесу.

На заключному етапі викладач оцінює результат роботи кожної групи та кожного слухача за виробленими критеріями оцінювання. Фіксується вихідний рівень знань, високо оцінюється нестандартне вирішення проблеми, яке можливе при опануванні додаткової літератури. Оцінюється ступінь самостійних рішень у розв'язанні поставленої задачі, ініціативи, точність виконання маніпуляцій, вміння працювати в команді. Вищі оцінки отримує та група слухачів, яка знайшла більш змістовне, раціональне обґрунтування вирішення поставленого завдання [8;10].

Прикладом використання інтерактивних методів навчання $є$ впровадження методу кооперативних груп на практичному занятті за темою "Лабораторна діагностика гемолітичних анемій".

При проведенні практичного заняття було створено три групи слухачів та три групи інтернів. Кожна група повинна була розробити план диореренційної діагностики гемолітичної анемії у пацієнта 3 різних точок зору.

Перша група слухачів та перша група інтернів вивчали морфологію еритроцитів, показники загального аналізу крові та кісткового мозку.

Друга група слухачів та друга група інтернів вивчали біохімічні показники крові та сечі.

Третя група слухачів та третя група інтернів оцінювали результати імунологічних досліджень прямої та непрямої проби Кумбса.

Наприкінці заняття кожна група звітувала про результати діагностики: формулювала загальні діагностичні висновки, враховуючи морфологічні, біохімічні та імунологічні показники.

При порівнянні трьох груп інтернів і трьох груп слухачів виявилося, що лікарі-інтерни краще орієнтувались у патогенезі та морфологічних методах дослідження, слухачі-біологи легше інтерпретува- 
ли результати біохімічних та імунологічних досліджень. Але й інтерни, і слухачі однаково впевнено вийшли на диференційний діагноз.

\section{Висновки}

Впровадження інтерактивних технологій у різних комбінаціях в практику навчання інтернів та слухачів з клінічної лабораторної діагностики дозволяє розвивати їх творче аналітичне мислення, розширити комунікативну компетентність, забезпечує фрормування здатності вибору оптимальних варіантів ефективної взаємодії як слухачів, так і викладачів, сприяє підвищенню мотивації до навчання даної дисципліни, що дозволяє підвищити фраховий рівень та вдосконалити диференційну діагностику.

Перспективи подальших досліджень полягають у проведенні поглибленої оцінки якості знань інтернів та слухачів із клінічної лабораторної діагностики у результаті використання інтерактивних технологій навчання.

\section{Список літератури}

1. Луцик Б. Д. Покращення підготовки спеціалістів лабораторної діагностики - вимога сучасності / Б. Д. Луцик, О. О. Ястремська // Лабораторна діагностика. - 2007. - № 3 (41). - С. 62-64.

2. Мокия-Сербина С. А. Применение основных положений доказательной медицины при подготовке специалистов по клинической лабораторной диагностике / С. А. Мокия-Сербина, Т. И. Ельчанинова, С. Г. Ситало // Лабораторна діагностика. - 2013. - № 4 (66). - С. 39-42.

3. Морозова В. Т. Подготовка преподавателей кафедр клинической лабораторной диагностики / В. Т. Морозова // Клиническая лабораторная диагностика. - 2001. - № 4. - С. 23-35.

4. Морозова В. Т. Подготовка специалистов для клинических лабораторий: мера традиций и поиска (комментарий координатора проблемы в научном комитете конгресса) / В. Т. Морозова // Клиническая лабораторная диагностика. 2001. - № 4. - С. 35-38.

5. Муц Б. М. Застосування педагогічних програмних засобів освіти в навчальному процесі вищої школи / Б. М. Муц // Медична освіта. - 2013. -№ 1. - С. 40-42.

6. Опыт сотрудничества при организации образования по лабораторной медицине / А. В. Индутный, В. Е. Высокогорский, Д. Б. Сапрыгин [и др.] // Клиническая лабораторная диагностика. - 2011. - № 7. -С. 50-53.

7. Подальші шляхи розвитку вищої освіти України / В. В. Лазоришинець, М. В. Банчук, О. П. Волосовець [та ін.] // Медична освіта. - 2010. - № 2. - С. 10-17.

8. Проблеми підготовки кадрів з діагностики туберкульозу для клініко-діагностичних лабораторій загальної лікувальної мережі та можливі шляхи поліпшення / Т. В. Іваненко, Т. В. Сенчева, М. Ф. Новохатська [та ін.] // Лабораторна діагностика. - 2012. - № 1 (59). - С. 39-41.

9. Рішення проблемних питань при впровадженні основних положень ЄКТС у ВНМУ ім. М. І. Пирогова / В. М. Мороз, Ю. Й. Гумінський, Л. Ф. Фоміна, Т. Л. Полеся // Медична освіта. - 2013. - № 2. -С. 40-42.

10. Сітало С. Г. Застосування інтерактивних методів навчання при викладанні клінічної лабораторної діагностики /

С. Г. Сітало, Т. І. Ельчанінова // Лабораторна діагностика. - 2015. - № 3 (73). - С. 15-17.

\section{ОРГАНИЗАЦИЯ ОБУЧЕНИЯ СЛУШАТЕЛЕЙ ПРОГРАММ ИНТЕРНАТУРЫ И СПЕЦИАЛИЗАЦИИ ПО СПЕЦИАЛЬНОСТИ «КЛИНИЧЕСКАЯ ЛАБОРАТОРНАЯ ДИАГНОСТИКА»}

О.Е. Сичкориз

Львовский национальный медицинский университет имени Данила Галицкого, г. Львов, Украина

Цель - подбор новых интерактивных методов обучения слушателей циклов интернатуры и специализации по специальности «Клиническая лабораторная диагностика».

Материалы и методы. Для оценки существующих и разработки новых методик интерактивных методов обучения применялись методы системного подхода и системного анализа.

Результаты. Предложено наряду со старыми педагогическими методами, которые определяются как «пассивные» и «монолог», использование новых интерактивных методов. Среди форм учебной деятельности интернов и слушателей по нормам современной педагогики наиболее подходит метод кооперативных групп.

Выводы. Внедрение интерактивных технологий обучения позволит решить следующие учебные цели: развитие критического мышления у слушателей циклов интернатуры и специализации по специальности «Клиническая лабораторная диагностика» и расширение их коммуникативной компетентности; фрормирование способности выбора оптимальных вариантов эфффективного взаимодействия участников; повышение мотивации к обучению данной дисциплины; совершенствование профессионального уровня слушателей и интернов по специальности «Лабораторная диагностика».

КЛЮЧЕВЫЕ СЛОВА: организация обучения, лабораторная диагностика, интерактивные методы обучения, метод кооперативных групп, циклы интернатуры.

\section{ORGANIZAZION OF TRAINING AT INTERNSHIP AND SPECIALIZATION PROGRAMS IN THE SPECIALTY "CLINICAL LABORATORY DIAGNOSTICS"}


O. Ye. Sichkoriz

Danylo Halytsky Lviv National Medical University, Lviv, Ukraine

Purpose: Selection of new interactive methods of teaching students at internship and specialization cycles in the specialty «Clinical Laboratory Diagnostics».

Materials and methods. Methods of system approach and system analysis were used to evaluate the existing and to develop new techniques of interactive teaching methods.

Results. Along with the old teaching methods defined as «passive» and «monologue», the use of new interactive methods is proposed. Among the forms of educational activity of interns and students according to the norms of modern pedagogy, the method of co-operative groups is considered the most appropriate.

Conclusions. Implementation of interactive teaching technologies will achieve the following learning objectives: development of critical thinking in students of internship and specialization cycles in «Clinical Laboratory Diagnostics» and expansion of their communicative competence; forming ability to select the best options of effective interaction between the participants; increase motivation to learn the discipline; improve the professional skills of students and interns in the specialty «Laboratory Diagnostics».

KEY WORDS: organization of training, laboratory diagnostics, interactive learning methods, method of co-operative groups, internship cycles.

Рукопис надійшов до редакції 24.10.2016 p.

\section{Відомості про автора:}

Січкоріз Орест Євгенович - к.мед.наук, доц. кафредри дитячих інфекційних хвороб Львівського національного медичного університету імені Данила Галицького; служб. тел.: +38 (032) 276-93-74. 